\title{
Increasing chloride concentrations in Lake Constance: characterization of sources and estimation of loads
}

\author{
Beat Müller • René Gächter
}

Received: 18 August 2010/Accepted: 16 March 2011/Published online: 31 March 2011

(C) Springer Basel AG 2011

\begin{abstract}
The chloride concentration in Lake Constance, by volume the second largest lake in Europe, has increased by a factor of 2.4 during the past 40 years. Based on a chloride budget for the year 2006, we estimated total chloride imports to the catchment at $101 \mathrm{kt} \mathrm{year}^{-1}$. Road deicing salts contributed $52 \%$, waste water $23 \%$, farming $11 \%$, soil weathering $9 \%$, precipitation and solid waste incineration $3 \%$ to this import. River monitoring programs in Switzerland, Germany, and Austria in 2006 traced an average total chloride export from the catchment into Lake Constance of almost $70 \mathrm{kt}$ and an export from the lake of $56 \mathrm{kt}$. About one-third of this load to the lake originated from the Alpine Rhine catchment (Switzerland), and about $60 \%$ from various smaller tributaries in Austria and Germany. The average annual import of chloride to Lake Constance for the years 1995-2007 was $60 \mathrm{kt}$, the export almost $57 \mathrm{kt}$. This budget is in good agreement with the observed increase in the chloride content of the lake and thus confirms the appropriateness and quality of the longterm monitoring program conducted by Swiss, German and Austrian laboratories. For the year 2006, we estimated that about $65 \%$ of the chloride spread onto roads for deicing and manure on cultivated land reached the lake within the year of their application. The missing 35\% remained transiently in the soil and groundwater of the catchment.
\end{abstract}

Keywords Lake constance - Chloride - Budget . Road deicing salt

B. Müller $(\bowtie) \cdot$ R. Gächter

Eawag, Swiss Federal Institute of Aquatic Science and Technology, 6047 Kastanienbaum, Switzerland

e-mail: beat.mueller@eawag.ch

\section{Introduction}

Sodium chloride $(\mathrm{NaCl})$ is used widely and in large amounts by the human society for various purposes. Despite the broad field of applications, only little is known about its sources and paths through anthropogenic systems, its behavior in the drainage basins of lakes, its effects on aquatic ecosystems, and the man-made acceleration of its environmental cycling (Klee and Graedel 2004).

Natural sources of chloride in freshwaters are (1) marine spray transferring $\mathrm{NaCl}$ into the atmosphere, transport as an aerosol by winds, and wash out by precipitation, and (2) the weathering of rocks. However, chloride in surface waters is to a large extent of anthropogenic origin, increasing with population density, the density of roads, intensification of farming, and solid waste incineration as the main sources. In several regions, the release of chloride is quite substantial. Since some freshwater systems in the northeastern United States approach $25 \%$ of seawater salinity, Kaushal et al. (2005) warned of a serious loss of drinking water resources and pointed to an increasing risk for freshwater life.

In countries with strong winters, $\mathrm{NaCl}$ applied for road deicing dominates all other sources of chloride release and can harm lake ecosystems (Novotny et al. 2008a). Kelly et al. (2008) reported a threefold concentration increase of chloride in a New York creek over 20 years and estimated that deicing salts, sewage, water softeners and natural background contributed $91,4,3$ and $2 \%$, respectively. In New Hampshire streams, Trowbridge et al. (2010) showed that $>90 \%$ of the chloride originated from road salt. Imported loads amounted to 45-98 $\mathrm{t} \mathrm{Cl}^{-} \mathrm{km}^{-2}$ year $^{-1}$ and were correlated with development in the watershed. Lundmark and Olofsson (2007) analyzing the salt content in soils along a major Swedish highway, discovered some 
$45 \%$ of the salt spread in the soil on both sides of the highway. A basin-wide estimation by Thunqvist (2004) estimated that the road salt accounted for half of the river's salt load. Novotny et al. (2008b) estimated that only about $22 \%$ of the road salt applied during the winter was exported from the drainage area but $78 \%$ remained transiently in the watershed. Similarly, Eyles and Meriano (2010) and Meriano et al. (2009) estimated that approximately half of the deicing salt applied in a city in Ontario, Canada, accumulated transiently in the groundwater and was later released as baseflow into streams during summer.

Degradation of groundwater resources is a major concern in growing urban areas, as elevated chloride concentrations are indicative of anthropogenic impact (Kelly 2008), and even approach the limits of drinking water quality standards (Howard and Maier 2007). Surveys in the Greater Toronto Area documented a strong relationship between increasing chloride concentration in the groundwater and urbanization (Williams et al. 1999; Howard and Maier 2007).

The water quality standard for chloride in the EU directive on surface water regulations is $0.25 \mathrm{~g} \mathrm{~L}^{-1}$ (EPA 2001). Hart et al. (1991) suspect adverse biological effects when salinity exceeds $1 \mathrm{~g} \mathrm{~L}^{-1}$. In outdoor mesocosm experiments, Petranka and Doyle (2010) showed that zooplankton (cladocerans and copepods) and frog eggs as well as hatchlings did not survive at concentrations $>1.2$ and $>4.5 \mathrm{~g} \mathrm{~L}^{-1}$, respectively. They further concluded that habitats affected by increased salt concentrations favored salt-tolerant insects.

As large lakes with a long water retention time react slowly to changing inputs, it is important to better understand the processes that control chloride cycling. In the Upper Lake Constance-located in the border triangle of Germany, Austria and Switzerland, the volume-weighted annual mean chloride concentration increased from 2.5 to $5.2 \mathrm{mg} \mathrm{L}^{-1}$ between 1961 and 1987 (Rossknecht 1998; Petri 2006). A recent 'Green Report' no. 35 (IGKB 2007) on the actual state of Lake Constance reported an all-time high of $6.1 \mathrm{mg} \mathrm{L}^{-1}$ in 2007 without quantifying the sources contributing to the observed concentration increase.

This work

- $\quad$ specifies and quantifies the various sources contributing to the lake's total chloride load.

- establishes the lake's chloride budget based on the import by the main tributaries in Switzerland, Germany and Austria, and data on the application of road deicing salt, urban wastewater, solid waste incineration, and agricultural livestock.

- confirms that chloride can be strongly retained in a lake's drainage basin, and

- demonstrates how seasonal changes in chloride load and water discharge combined with the alteration of lake mixing and stratification affect accumulation of chloride in Lake Constance.

\section{Materials and methods}

Switzerland, Germany and Austria are bordering Lake Constance, a deep peri-alpine lake of $48.5 \mathrm{~km}^{3}$ volume (see Fig. 1). It is separated into the Upper and Lower Lake Constance with maximum depths of 254 and $46 \mathrm{~m}$, and volumes of 47.6 and $0.8 \mathrm{~km}^{3}$, respectively. The corresponding water residence times of the two basins amount to about 4.3 years and 1 month. About $50 \%$ of the catchment area is in Switzerland and Liechtenstein, 28\% in Germany, $22 \%$ in Austria, and a tiny part in Italy. The main tributary is the Alpine Rhine contributing about $64 \%$ to the total annual water load (Table 1).

In order to establish the chloride budget of Lake Constance, we used the following datasets:

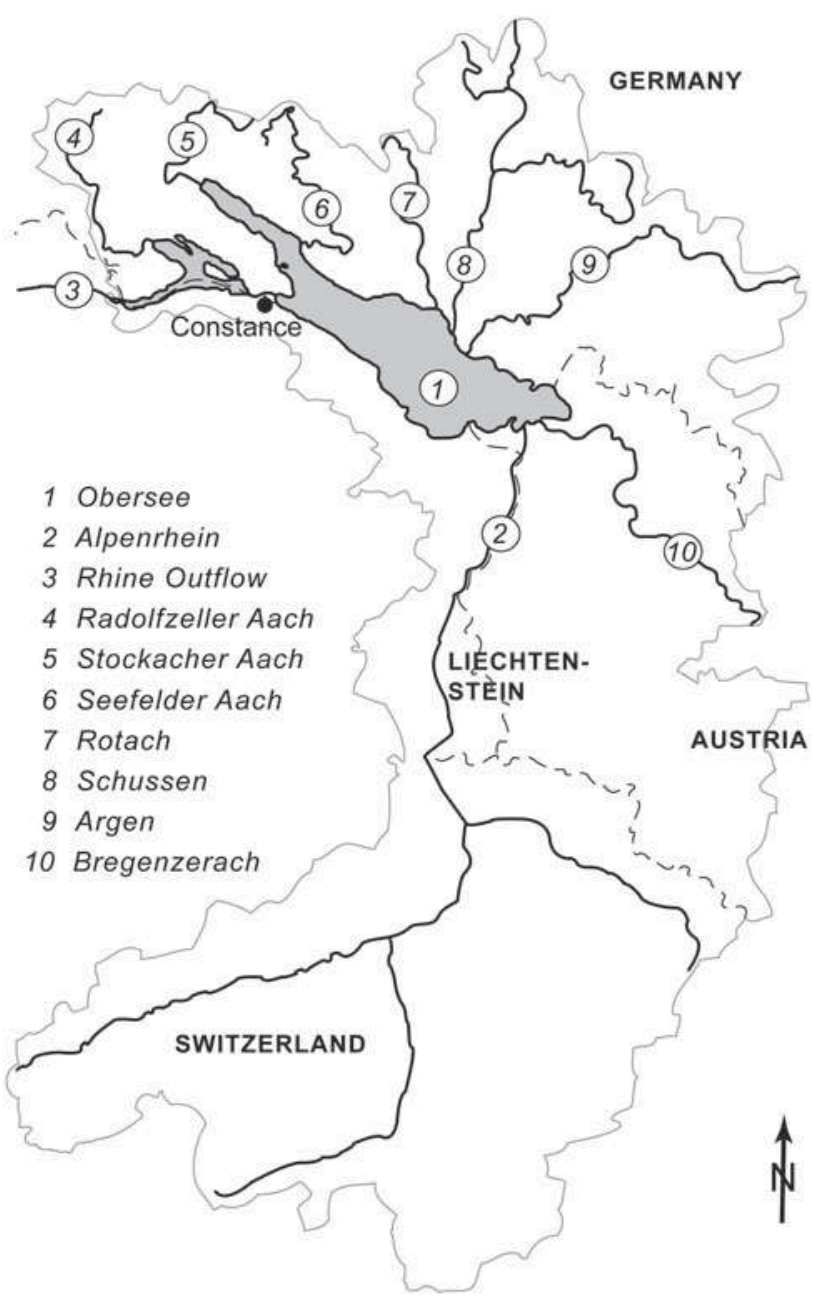

Fig. 1 Map of Lake Constance with bordering countries and main tributaries 
Table 1 Morphological and hydrographic data for Lake Constance (LC) and the Alpine Rhine

\begin{tabular}{|c|c|c|}
\hline & $\begin{array}{l}\text { Upper } \\
\text { LC }\end{array}$ & $\begin{array}{l}\text { Lower } \\
\text { LC }\end{array}$ \\
\hline Surface area $\left(\mathrm{km}^{2}\right)^{\mathrm{a}}$ & 473 & 62 \\
\hline Volume $\left(\mathrm{km}^{3}\right)^{\mathrm{a}}$ & 47.6 & 0.8 \\
\hline Max. depth $(\mathrm{m})^{\mathrm{a}}$ & 253 & 40 \\
\hline Residence time (year) ${ }^{\mathrm{a}}$ & 4.3 & 0.08 \\
\hline Catchment area $\left(\mathrm{km}^{2}\right)^{\mathrm{a}}$ & 10,919 & 555 \\
\hline $\begin{array}{l}\text { Catchment area Alpine Rhine upstream of } \\
\text { Diepoldsau }\left(A_{\mathrm{AR}}\right)\left(\mathrm{km}^{2}\right)\end{array}$ & 6,564 & \\
\hline $\begin{array}{l}\text { Lake Constance, downstream of Diepoldsau }\left(A_{\mathrm{R}}\right) \\
\quad\left(\mathrm{km}^{2}\right)\end{array}$ & 3,753 & \\
\hline $\begin{array}{l}\text { Mean water discharge (1997-2007 av.) Alpine Rhine } \\
\left(\mathrm{m}^{3} \mathrm{~s}^{-1}\right)^{\mathrm{b}}\end{array}$ & 233.6 & \\
\hline $\begin{array}{l}\text { Mean water discharge }(1997-2007 \text { av. }) \text { total } \\
\text { catchment }\left(\mathrm{m}^{3} \mathrm{~s}^{-1}\right)^{\mathrm{c}}\end{array}$ & 366.8 & \\
\hline Water withdrawal for drinking water $\left(\mathrm{km}^{3} \text { year }{ }^{-1}\right)^{\mathrm{d}}$ & 0.17 & \\
\hline \multicolumn{3}{|l|}{ a Petri (2006) } \\
\hline \multicolumn{3}{|l|}{ b Gauge station Diepoldsau $(\mathrm{CH})$} \\
\hline${ }^{\mathrm{c}}$ Gauge station Neuhausen $(\mathrm{CH})$ & & \\
\hline${ }^{\mathrm{d}}$ http://www.zvbwv.de & & \\
\hline
\end{tabular}

1. Bi-weekly monitored chloride concentration profiles over 12 depths from the long-term monitoring program of Lake Constance for the period 1961-2007 (IGKB 2007). Annual export loads were estimated from the mean concentrations of the lake, corrected for the seasonal chloride depletion of the surface layer (see below), and the water discharge measured at the gauge station at Neuhausen (hydrological dataset of the Swiss Federal Office for the Environment, FOEN 2288).

2. Chloride concentrations and water discharge of the Alpine Rhine, the main tributary to Lake Constance, were measured in bi-weekly composite samples that were collected quasi-continuously in proportion to water discharge at the gauge station Diepoldsau between 1984 and 2009 (Swiss National River Monitoring and Survey Program, NADUF 2009).

3. Chloride concentration and water discharge data of the Austrian tributary Bregenzer Ach in the period 1995-2007 were provided by the Office for Environment and Food, and the Office for Water Economy, Bregenz.

4. Chloride concentration and water discharge data of the German tributaries Schussen, Argen, Rotach, Seefelder Aach, Stockacher Aach and Radolfzeller Aach in the period 1995-2007 were provided by the Landesanstalt für Umwelt, Messungen und Naturschutz Baden-Württemberg (LUBW), Germany. The monitored tributaries cover more than $96 \%$ of the water discharge to the lake (Gurtz et al. 1997). The German and Austrian tributaries were monitored since 1995 and 1989, respectively, with about 40 and 15 individual samples annually. For the major tributaries Argen and Schussen, a water discharge dataset with daily values was provided, from which we estimated the chloride load for 2006 based on derived concentration-discharge relationships as described in Moosmann et al. (2005).

5. A list of water discharge data and person equivalents from sewage treatment plants discharging directly into the lake was provided from the Swiss Federal Office for the Environment (FOEN). E. Butscher (Umwelt und Energie, Lucerne) provided information on representative chloride concentrations in urban wastewater. Based on 9 wastewater treatment plants and about 30 measurements each during the period 2000-2007 about $22 \pm 8 \mathrm{~g} \mathrm{Cl}^{-}$per day and population equivalent (PE) was estimated during the summer months, corresponding to about $8 \mathrm{~kg} \mathrm{Cl}^{-}$year $^{-1}$ per PE.

6. The Cantonal Office for Environment and Energy, St. Gallen, provided an extensive dataset on livestock in Switzerland, Germany, Austria and Liechtenstein for the years 1980-2007. To estimate the livestock within the lake's drainage basin in 2006, we

- considered the information provided by the Canton of St. Gallen for the individual villages situated in the lake's catchment,

- added the total numbers obtained for the Canton Graubünden, Liechtenstein and Vorarlberg,

- but included only $50 \%$ of the total livestock registered in the German states of Bayern and Baden-Württemberg corresponding to the approximate fractions of their land located within the lake's drainage basin.

7. The Environmental Protection Bureaus of the Cantons of St. Gallen, Thurgau and Graubünden provided data on deicing salt applied in the catchment of the Alpine Rhine and along the southern shore of Lake Constance. Corresponding data from the German districts Ravensburg, Friedrichshafen and Konstanz were supplied by the Landesanstalt für Umwelt, Messungen und Naturschutz Baden-Württemberg, Germany (LUBW). Numbers from Vorarlberg (A) were taken from the internet (Vorarlberg 2009).

8. The chloride loads from the solid waste incineration plants Buchs (SG) and Trimmis (GR) were calculated from the weight of incinerated waste. Weekly or bi-weekly routine measurements from the operating 
company results in a minimum of $6 \mathrm{~g} \mathrm{Cl}^{-} \mathrm{kg}^{-1}$ and a maximum of $9.5 \mathrm{~g} \mathrm{Cl}^{-} \mathrm{kg}^{-1}$ waste. We used the mean value of $7.8 \mathrm{~g} \mathrm{Cl}^{-} \mathrm{kg}^{-1}$ for our estimation. (Data from Amt für Umwelt und Energie, St. Gallen, and Amt für Natur und Umwelt, Graubünden).

9. Eight diverse manure samples were collected from farms with different composition of livestock, and analyzed for total dissolved phosphorus (TDP), total dissolved nitrogen (TDN) and chloride using standard analytical methods (DEW 2002).

10. Chloride concentration in rainwater was estimated by averaging the mean annual concentrations observed in 2007 at five representative monitoring stations from the Swiss National Air Pollution Monitoring Network (NABEL 2007).

11. Sixteen water works around the lake withdraw an annual average of 172 million $\mathrm{m}^{3}$ for drinking water supply (Bodensee-Wasserversorgung).

The budget of chloride for Lake Constance, therefore, balances contributions of domestic waste water $L_{\text {Sewer }}$, exhaust washing water of solid waste incineration plants, $L_{\text {Incin }}$, road deicing salt, $L_{\text {Deicing, }}$, chloride leached out of soil, $L_{\text {Soil }}$, chloride imported by precipitation, $L_{\text {Precip }}$ : with the export through the outlet, $L_{\text {out }}$, and the withdrawal for drinking water supply, $L_{\mathrm{Ws}}$ :

$$
\begin{aligned}
V \frac{\Delta\left[\mathrm{Cl}^{-}\right]}{\Delta t}= & L_{\text {Sewer }}+L_{\text {Incin }}+L_{\text {Deicing }}+L_{\text {Soil }} \\
& +L_{\text {Precip }}-L_{\text {out }}-L_{\mathrm{WS}}
\end{aligned}
$$

$V$ is the volume of the lake and $\Delta\left[\mathrm{Cl}^{-}\right] / \Delta t$ the change in the lake's average chloride concentration during the time $\operatorname{span} \Delta t$.

\section{Results and discussion}

As Fig. 2 shows, the mean annual chloride concentration of the Upper Lake Constance increased mainly in three phases, by $2.5 \mathrm{mg} \mathrm{L}^{-1}$ between 1968 and 1980 , by $1.8 \mathrm{mg} \mathrm{L}^{-1}$ between 1985 and 1988 , and by another $1.2 \mathrm{mg} \mathrm{L}^{-1}$ between 2003 and 2007. Short periods of decreasing concentration occurred between 1980-1985, 1988-1990, and 1992-1996 by $0.7,0.8$, and $0.7 \mathrm{mg} \mathrm{L}^{-1}$. A Mann-Kendall trend test confirms the general upward trend with $t=0.68$ and $p=3.9 \times 10^{-11}$. The annual mean chloride concentrations of the Alpine Rhine and of the remaining catchment both show the increasing tendency as well. The mean concentrations calculated from monitoring data of seven major tributaries in Germany and Austria exceeded the lake water concentration about twofold, and the concentration of the Alpine Rhine about three to fivefold.

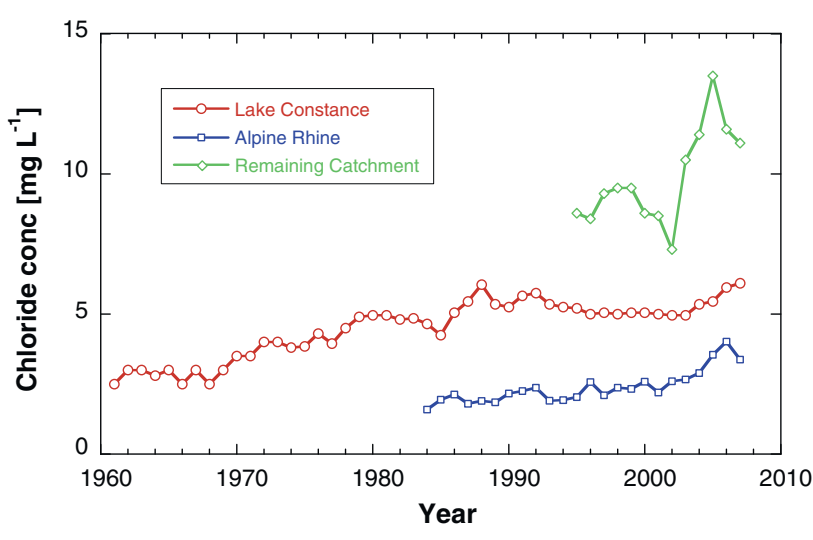

Fig. 2 Mean annual concentration of $\mathrm{Cl}^{-}$in the Upper Lake Constance from 1961 to 2007 (red circles). Concentrations are calculated as weighted averages from monthly samples over the whole water column at the deepest site. Mean concentrations of the Alpine Rhine (blue squares) were calculated from NADUF data. Concentrations for the remaining catchment were estimated from monitoring data of the rivers Argen (D), Schussen (D), Rotach (D), Stockacher Aach (D), Radolfzeller Aach (D), and Bregenzeraach (A) available since 1995 (green diamonds)

A more detailed look at the hydrological regime of the Alpine Rhine since 1984 in Fig. 3a shows strong seasonal variations with minimum water discharges in winter and peak flows in summer. Contrary to the winter minima varying quite regularly with a frequency of 0.2 year $^{-1}$, the amplitudes of the summer peaks did not show an obvious regularity. The chloride load (Fig. 3c) often peaked in early summer when the water discharge (Fig. 3a) was low. However, additional sharp and high peaks appeared in all seasons. The increasing trend in chloride concentration in Lake Constance shown in Fig. 2, and the increasing trend in chloride load (Fig. 3c) opposing the long-term trend of the water discharge (Fig. 3a) are indications that the increased chloride load to the lake is not due to increased river discharge. The seasonal Mann-Kendall test confirmed the increasing trend for chloride concentration and load with $t=0.23$, $p=2.6 \times 10^{-9}$, and $t=0.41, p=<2.2 \times 10^{-16}$, while the trend of the water discharge was very weak with $t=0.016, p=0.69$.

Chloride behaves conservatively in surface waters, i.e., it does not participate in biogeochemical processes, and its uptake by phytoplankton is negligible compared to the large reservoir. Thus, the steady state chloride concentration in the lake must equal the mean input concentration of all tributaries, $\left[\mathrm{Cl}^{-}\right]_{\text {in }}$ independent of the lake's flushing rate. However, as shown in Fig. 4, the surface water concentration, $\left[\mathrm{Cl}^{-}\right]_{0}$, during the stratification period can be up to $25 \%$ below the depth averaged concentration, $\left[\mathrm{Cl}^{-}\right]_{\text {mean }}$ : 
$\beta_{\mathrm{aver}}=\frac{\left[\mathrm{Cl}^{-}\right]_{0}}{\left[\mathrm{Cl}^{-}\right]_{\text {mean }}}$

This is a consequence of the high import of $\mathrm{Cl}^{-}$during winter and early spring (see Fig. 3c) when the lake is not stratified. With progressing stratification, the tributaries carry lower $\mathrm{Cl}^{-}$loads and, together with rain, remain in the lake surface layer causing its transient chloride depletion. As a consequence, the annual average chloride concentration of the water leaving the lake via its outlet is about $7 \%$ lower than the average lake concentration, resulting in $\beta_{\text {aver }}=0.93$. This is an important process contributing to the accumulation of chloride in the lake in spite of its conservative behavior.

Apart from the $\mathrm{Cl}^{-}$export via the lake's main outlet, the drinking water withdrawal by 16 water works amounting to 172 million $\mathrm{m}^{3}$ year ${ }^{-1}$, or $1.0 \mathrm{kt}^{-} \mathrm{Cl}^{-}$in the year 2006 is the only considered sink. A possible but likely insignificant influence of groundwater to the lake's $\mathrm{Cl}^{-}$balance was neglected due to the sparseness of data.

Due to the law of mass conservation, the chloride concentration in the lake can only increase at times when the average concentration of all tributaries exceeds the lake's surface water concentration. In case of the Alpine Rhine, this situation prevails only during a few winter months (compare Figs. 2, 3b, 4). During these periods, however,

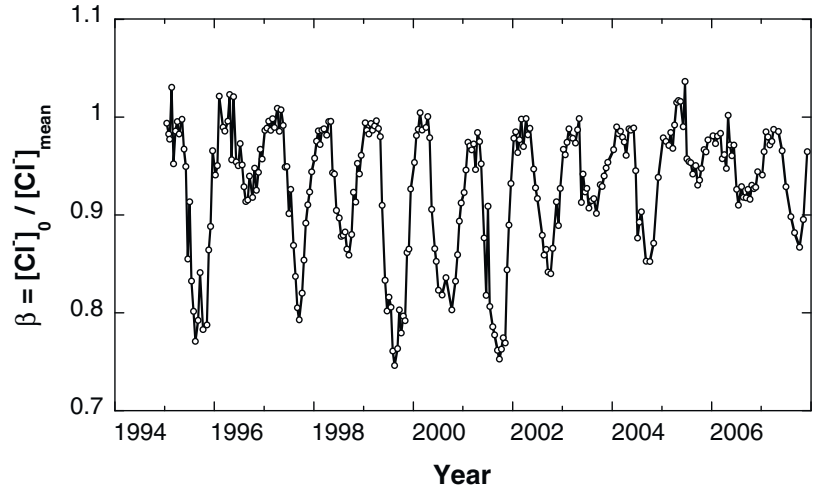

Fig. 4 Seasonal depletion of the chloride concentration at the lake's surface, $\left[\mathrm{Cl}^{-}\right]_{0}$, compared to the mean concentration over all depths, $\left[\mathrm{Cl}^{-}\right]_{\text {mean }}$, from 1995 to 2007 . The ratio is expressed as $\beta=\left[\mathrm{Cl}^{-}\right]_{0} /$ $\left[\mathrm{Cl}^{-}\right]_{\text {mean }}$

water discharge of the Alpine Rhine is minimal and thus carries only a small load (Fig. 3c). For the rest of the year, the Alpine Rhine dilutes the lake water with respect to chloride, suggesting that it cannot explain the chloride concentrations increasing up to the present level.

In the following we draw a detailed picture of all relevant sources that constitute the chloride concentration in Lake Constance (Table 2).
Fig. 3 a Hydrological regime of the Alpine Rhine (gauge station Diepoldsau), b seasonal variation of the chloride concentration, and $\mathbf{c}$ the chloride load in $\mathrm{kg} \mathrm{s}^{-1}$ in the time from 1984 to 2007. Data from NADUF

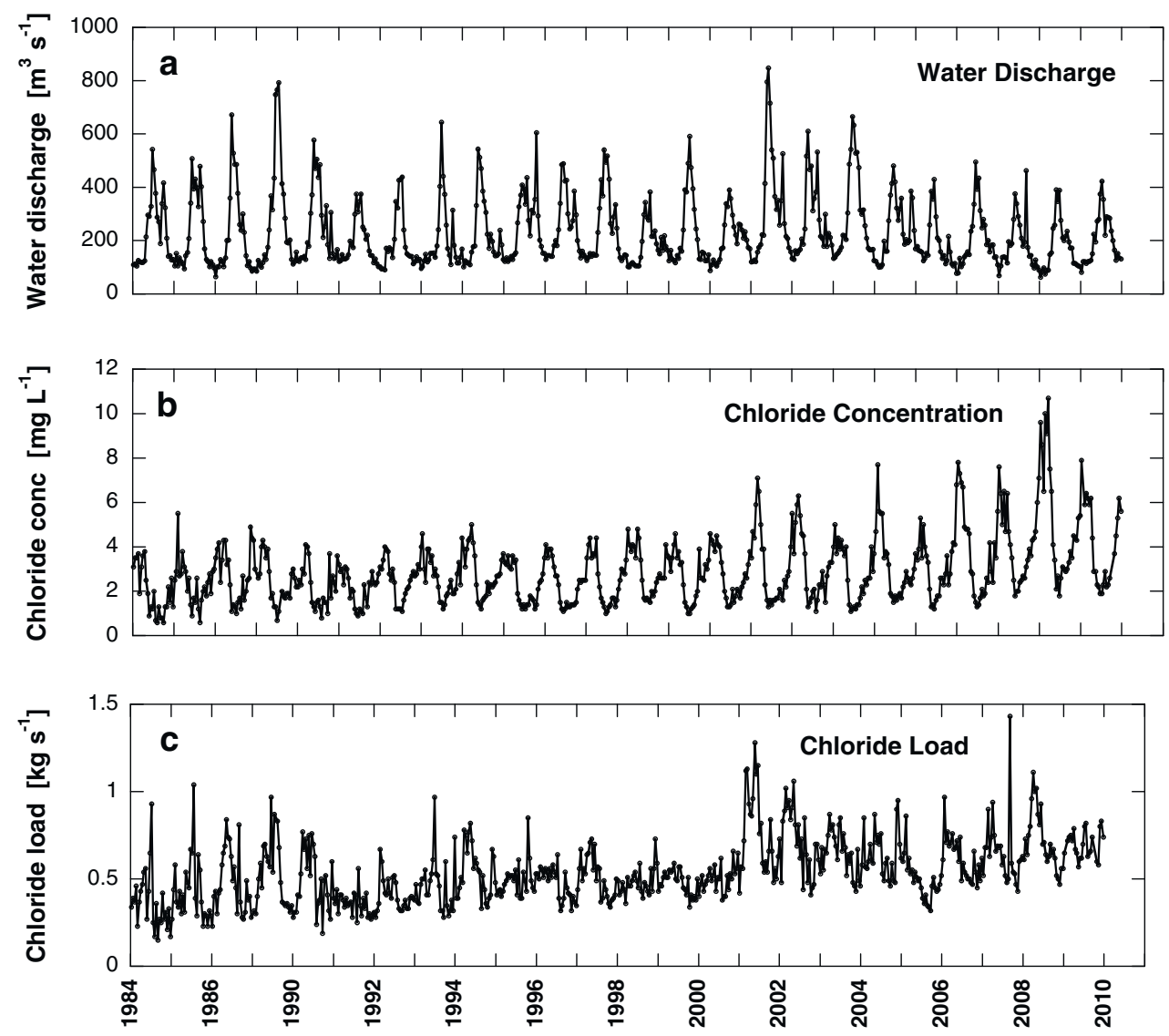




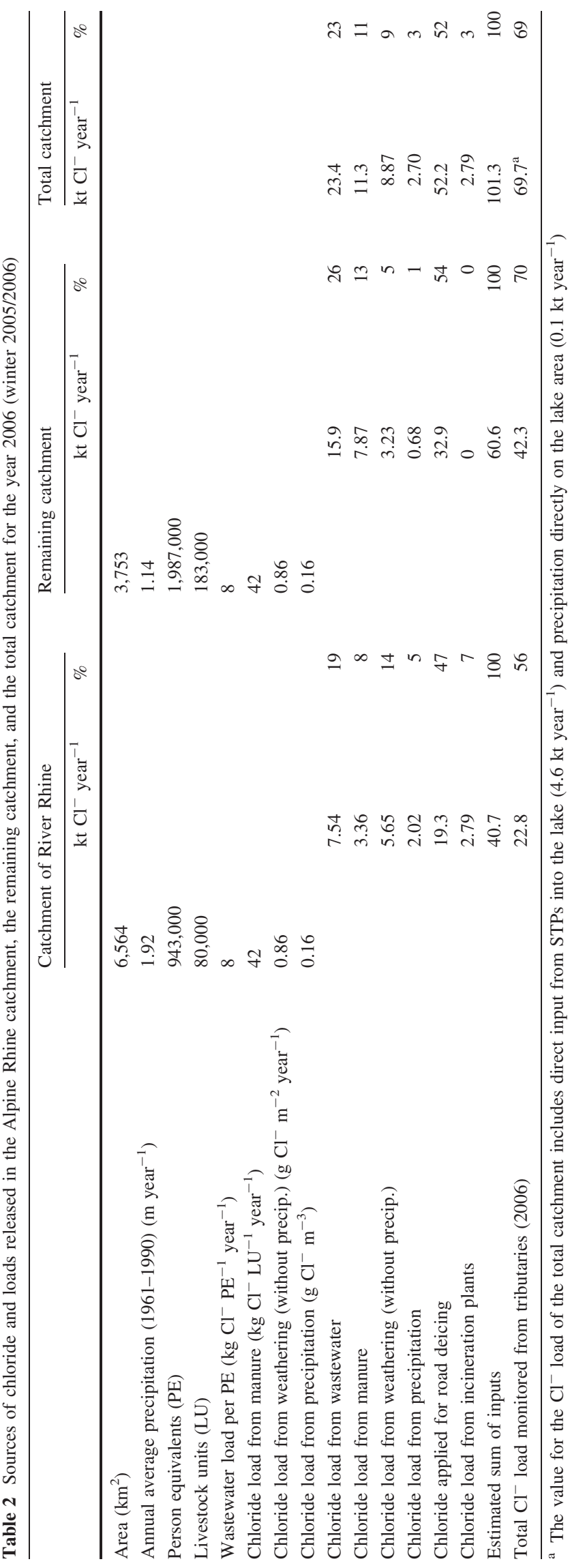

\section{Tributaries}

The River Rhine contributes about 35\% and the German and Austrian tributaries add the remaining $65 \%$ to the total annual chloride input to Lake Constance. From 1995 to 2002 , the total measured loads approximately matched the estimated export, whereas from 2003 to 2006 the import exceeded the export (Table 3). This agrees well with the observation that from 1995 to 2002 the in-lake chloride concentration decreased but increased afterwards (Fig. 2). Figure 5 depicts the progression of the lake's chloride content starting out from the content in the year 1994 and adding the annual difference between monitored input and output (Table 3), and compares it with the lake's chloride content obtained from the biweekly monitoring program. The striking consistency of the two datasets indicates that the presented budget considers all relevant sources with excellent accuracy.

Urban wastewater

Applying the estimated annual release of $8 \mathrm{~kg} \mathrm{Cl}^{-}$per person equivalent to the population of 943,000 in the catchment of the Alpine Rhine suggests that wastewater contributed $7.54 \mathrm{kt}^{\text {year }}{ }^{-1}$ corresponding to about $1 / 3$ of the annual $\mathrm{Cl}^{-}$load of the Alpine Rhine. Eighteen sewage treatment plants discharge directly into the lake and thus were not included in the river monitoring. They treated wastewater of 578,000 inhabitants (Federal Office for the Environment, FOEN) releasing $4.62 \mathrm{kt} \mathrm{Cl}^{-}$, or $6-10 \%$ of the total annual chloride load to Lake Constance (Table 3).

Solid waste incineration

In Switzerland, solid waste is incinerated. The exhaust of the incineration plants is washed with water, which after treatment is released to surface waters. In 2006, the incineration plants from Buchs and St. Gallen released $1.99 \mathrm{kt} \mathrm{Cl}^{-}$year $^{-1}$, and Trimmis $0.80 \mathrm{kt} \mathrm{Cl}^{-}$year $^{-1}$. No solid waste incineration plants exist in the German and Austrian parts of the catchment of Lake Constance.

Weathering and atmospheric input

A representative average chloride concentration in rainwater was calculated from five stations of the Swiss National Air Pollution Monitoring Network (NABEL 2007) covering rural and urban areas. Data collected since 1985 showed a significant initial decrease of chloride concentrations in the rainwater of urban areas that remained approximately constant since 1995 . We estimated an average concentration of $0.16 \mathrm{~g} \mathrm{~m}^{-3}$. Long-term average annual precipitation (1961-1990) on the whole 
Table 3 Averaged annual loads of chloride to and from Lake Constance calculated from monitoring data

\begin{tabular}{|c|c|c|c|c|c|c|c|c|c|c|c|c|c|c|}
\hline \multirow[t]{2}{*}{ Year } & \multicolumn{2}{|l|}{$\mathrm{Cl}^{-}$export } & \multicolumn{10}{|c|}{$\mathrm{Cl}^{-}$import by individual rivers } & \multirow{2}{*}{\multicolumn{2}{|c|}{$\begin{array}{l}\text { Total Cl } \\
\text { import } \\
\text { In \% of } \\
\text { export }\end{array}$}} \\
\hline & $\begin{array}{l}\text { Lake } \\
\left(\text { kt year }^{-1}\right)\end{array}$ & $\begin{array}{l}\text { Water- } \\
\text { supply } \\
\left(\text { kt year }^{-1}\right)\end{array}$ & $\begin{array}{l}\text { Alpine } \\
\text { Rhine } \\
\text { (kt year }^{-1} \text { ) }\end{array}$ & $\begin{array}{l}\text { Argen } \\
\left(\text { kt year }^{-1}\right)\end{array}$ & $\begin{array}{l}\text { Schussen } \\
\left(\text { kt year }^{-1}\right)\end{array}$ & $\begin{array}{l}\text { Rotach } \\
\left(\text { kt year }^{-1}\right)\end{array}$ & $\begin{array}{l}\text { Seefelder } \\
\text { Aach } \\
\left(\text { kt year }^{-1}\right)\end{array}$ & $\begin{array}{l}\text { Stockacher } \\
\text { Aach } \\
\left(\text { kt year }^{-1}\right)\end{array}$ & $\begin{array}{l}\text { Radolfzeller } \\
\text { Aach } \\
\left(\mathrm{kt} \mathrm{year}^{-1}\right)\end{array}$ & $\begin{array}{l}\text { Bregenzerach } \\
\left(\text { kt year }^{-1}\right)\end{array}$ & $\begin{array}{l}\text { Precipitation } \\
\left(\text { kt year }^{-1}\right)\end{array}$ & $\begin{array}{l}\text { STP direct } \\
\text { input } \\
\left(\mathrm{kt} \mathrm{year}^{-1}\right)\end{array}$ & & \\
\hline 1995 & 64.8 & 0.88 & 16.2 & 8.13 & 7.77 & 1.36 & 2.53 & 2.04 & 6.94 & 2.87 & 0.1 & 4.62 & 52.58 & 80 \\
\hline 1996 & 44.0 & 0.83 & 15.3 & 5.28 & 6.84 & 0.87 & 1.86 & 1.15 & 7.25 & 3.52 & 0.1 & 4.62 & 46.810 & 106 \\
\hline 1997 & 50.7 & 0.87 & 15.2 & 5.27 & 8.38 & 0.95 & 1.77 & 0.94 & 7.12 & 2.94 & 0.1 & 4.62 & $47.3 \quad 9$ & 93 \\
\hline 1998 & 48.1 & 0.86 & 15.9 & 6.19 & 12.7 & 1.27 & 2.71 & 1.43 & 5.53 & 2.48 & 0.1 & 4.62 & 52.911 & 110 \\
\hline 1999 & 75.1 & 0.87 & 24.2 & 12.6 & 8.21 & 1.47 & 3.50 & 2.62 & 7.54 & 4.41 & 0.1 & 4.62 & 69.39 & 92 \\
\hline 2000 & 64.6 & 0.88 & 22.6 & 9.56 & 10.4 & 0.84 & 2.39 & 1.89 & 8.00 & 5.38 & 0.1 & 4.62 & $\begin{array}{ll}65.8 & 10\end{array}$ & 102 \\
\hline 2001 & 63.8 & 0.87 & 20.4 & 7.01 & 10.1 & 1.25 & 2.83 & 2.57 & 7.54 & 4.11 & 0.1 & 4.62 & 60.5 & 95 \\
\hline 2002 & 60.2 & 0.87 & 20.4 & 7.35 & 7.84 & 1.78 & 2.78 & 2.13 & 6.41 & 4.21 & 0.1 & 4.62 & $57.6 \quad 9$ & 96 \\
\hline 2003 & 41.8 & 0.91 & 15.5 & 5.39 & 16.1 & 1.21 & 1.85 & 1.82 & 6.38 & 4.51 & 0.1 & 4.62 & $\begin{array}{ll}57.5 & 13\end{array}$ & 138 \\
\hline 2004 & 51.5 & 0.94 & 19.5 & 8.50 & 10.6 & 3.45 & 3.97 & 3.51 & 11.5 & 7.39 & 0.1 & 4.62 & $\begin{array}{ll}73.1 & 14\end{array}$ & 142 \\
\hline 2005 & 49.6 & 0.94 & 20.8 & 9.35 & 12.5 & 1.84 & 2.67 & 1.87 & 8.63 & 6.04 & 0.1 & 4.62 & 68.413 & 138 \\
\hline 2006 & 55.1 & 1.0 & 22.8 & 10.3 & 8.62 & 1.94 & 2.92 & 2.88 & 9.05 & 6.51 & 0.1 & 4.62 & $69.7 \quad 12$ & 126 \\
\hline 2007 & 59.2 & 1.0 & 21.7 & 8.03 & 6.57 & 1.50 & 2.40 & 1.58 & 7.81 & 4.27 & 0.1 & 4.62 & 58.69 & 99 \\
\hline $\begin{array}{r}\text { Annual } \\
\text { mean }\end{array}$ & 56.0 & 0.92 & 19.3 & 7.92 & 9.74 & 1.52 & 2.63 & 2.03 & 7.66 & 4.51 & 0.1 & 4.62 & 60.0 & \\
\hline
\end{tabular}

Export from the lake was calculated from water discharge at station Neuhausen and the average annual concentration published in IGKB (2007) corrected for the temporal depletion of chloride from the surface layer ( $\beta=0.93$, see text). 'Direct input' estimates the load from sewage treatment plants (STP) that discharge directly into the lake and are thus not recorded by the monitoring

of tributaries 


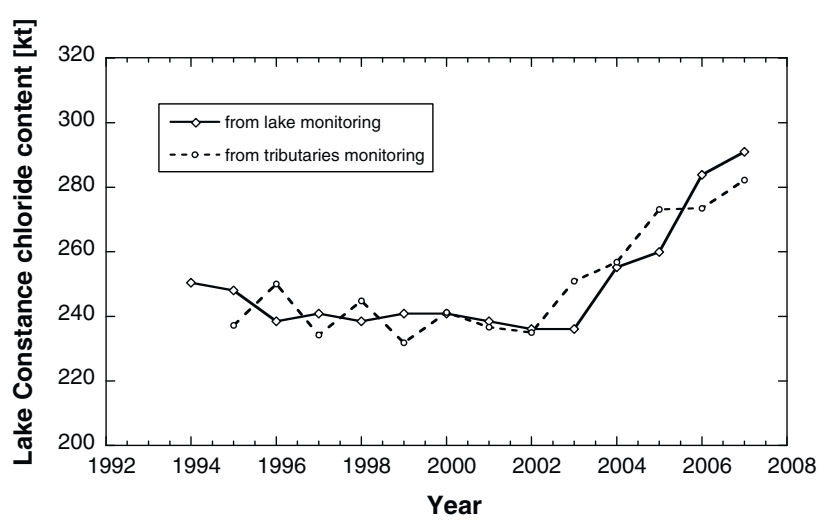

Fig. 5 Chloride content of Lake Constance calculated from biweekly lake monitoring data (diamonds, bold line). Circles (dotted line) depict the progression of the lake's chloride content estimated from tributaries monitoring, direct inputs, and export (data from Table 3), starting from the content in $1994(250 \mathrm{kt})$

catchment is 1,559 mm year ${ }^{-1}$ (CRU 1961-1990). The Alpine Rhine sub-catchment receives 1,919 $\mathrm{mm} \mathrm{year}^{-1}$, corresponding to a chloride load of $2.02 \mathrm{kt} \mathrm{year}^{-1}$. The remaining catchment precipitation of $1,138 \mathrm{~mm} \mathrm{year}^{-1}$ adds another $0.68 \mathrm{kt}$ year $^{-1}$. In order to estimate the precipitation directly onto the lake surface, we used the 30 -year average precipitation of 1,309 $\mathrm{mm}$ at the station St. Gallen (Switzerland), resulting in an annual chloride input of $0.10 \mathrm{kt} \mathrm{Cl}^{-}$year $^{-1}$. All data are presented in Table 2 .

For estimation of natural weathering, we used the export rate of chloride from extensively used land (extensive farming, forest, and barren land) of $1 \mathrm{~g} \mathrm{~m}^{-2}$ year $^{-1}$ from Zobrist and Reichert (2006), which includes also the load from precipitation.

\section{Road deicing salt}

In Germany as well as in Switzerland, highways are serviced by the counties/cantons while municipal roads are the responsibility of municipalities. Collecting information on road salt applications was an elaborate task, and the compiled loads certainly underestimate the true loads, also because not all municipalities could provide data and no information from the private sector could be included. Amounts of salt applications varied by a factor of five between years but were $7.35,5.40,3.73 \mathrm{kt} \mathrm{Cl}^{-}$in the Landkreis Ravensburg, Friedrichshafen and Konstanz in 2005/2006 and $5.40 \mathrm{kt} \mathrm{Cl}^{-}$in Bayern in 2008/2009. In the Vorarlberg region, more than $10 \mathrm{kt}$ of salt (corresponding to $6.0 \mathrm{kt} \mathrm{Cl}^{-}$) is used in a hard winter. According to the available information, road salt application reached an all time high in all areas in the winters $2004 / 2005$ and 2005/2006. This may have contributed significantly to the most recent increase in the lakes chloride concentration.
As can be seen from Table 2, deicing salt dominated all other inputs. Furthermore, depending on winter weather conditions, it is the most variable chloride source but correlates amazingly well with average winter temperatures (Table 4). According to information obtained from the St. Gallen Cantonal Office for Environment and Energy, loads (as $\mathrm{NaCl}$ ) vary between $2.2 \mathrm{kt}$ (in the warm winter of 2002/2003) and almost $18 \mathrm{kt}$ (2005/2006, corresponding to $10.9 \mathrm{kt} \mathrm{Cl}^{-}$). The public works service administration of the Canton Graubünden applied $13.1 \mathrm{kt} \mathrm{NaCl}$ (corresponding to $7.96 \mathrm{kt} \mathrm{Cl}^{-}$) in the winter 2005/2006 within the catchment of Lake Constance. The Canton Thurgau and municipalities in the catchment applied $1.02 \mathrm{kt} \mathrm{Cl}^{-}$, and the Principality of Liechtenstein applied $0.46 \mathrm{kt}$ of chloride.

If the amount of chloride applied as deicing salts in the Alpine Rhine catchment (19.3 kt) would be transferred to surface waters during the four winter months a mean load of $1.9 \mathrm{~kg} \mathrm{~s}^{-1}$ resulted on top of the base load in late summer and fall. Contrary to this expectation, Fig. 6 shows that the chloride discharge of the Alpine Rhine raised only by $0.2-0.4 \mathrm{~kg} \mathrm{~s}^{-1}$ during the period March to June, suggesting that the main fraction of the deicing salt does not readily flow via street sewers into surface waters but rather seeps into soils from where it is leached slowly, probably only during the precipitation-rich spring and summer month, and possibly only after many years. As shown in Table 2, input and output of chloride do not balance in the River Rhine catchment. Even on an annual basis, the input is almost twice as high as the output (monitored by the NADUF program). The only possible transient storage for chloride is its accumulation in the soil, especially along roadsides and in groundwater. Point sources $\left(L_{\text {sewage }}\right.$ and $\left.L_{\text {incin }}\right)$ that discharge chloride directly into the water, contributed $10.3 \mathrm{kt} \mathrm{Cl}^{-}$year ${ }^{-1}$ to the load determined in the River Rhine leaving only $12.4 \mathrm{kt} \mathrm{Cl}^{-}$year ${ }^{-1}$ to be washed out of the soil. Accordingly, in 2006 soil and groundwater stored $18.0 \mathrm{kt} \mathrm{Cl}^{-}$year $^{-1}$.

\section{Agriculture}

Apart from deicing salt, manure applied to cultivated land and the weathering of soil contribute to chloride transfer from soil to surface waters. In the drainage basins of Lake Constance, livestock is statistically documented. One livestock unit (LU) is equivalent to a dairy cow of $600 \mathrm{~kg}$ weight generating $15 \mathrm{~kg} \mathrm{P}$ and $105 \mathrm{~kg} \mathrm{~N}$ per year as manure (FOEFL 1994). We analyzed eight different manure samples from the Canton of Lucerne and observed average N/P, $\mathrm{Cl} / \mathrm{P}$ and $\mathrm{Cl} / \mathrm{N}$ ratios of $8.3,2.9$, and 0.4 , respectively (Table 5). Based on the $\mathrm{Cl} / \mathrm{N}$ and the $\mathrm{Cl} / \mathrm{P}$ ratios and the mentioned annual $\mathrm{N}$ and $\mathrm{P}$ production rates, we estimated an average chloride excretion of $42 \mathrm{~kg}$ year $^{-1}$. Probably 
Table 4 The annual applications of road deicing salt (expressed in $t \mathrm{Cl}^{-}$) correlate with the average temperature of December to February

\begin{tabular}{|c|c|c|c|c|c|c|c|}
\hline Winter & $\begin{array}{l}\text { Average } \\
\text { temp. }\left({ }^{\circ}\right)\end{array}$ & $\begin{array}{l}\text { Ravensburg (kt } \\
\left.\mathrm{Cl}^{-} \text {year }^{-1}\right)\end{array}$ & $\begin{array}{l}\text { Friedrichshafen } \\
\left(\mathrm{kt} \mathrm{Cl}^{-} \text {year }^{-1}\right)\end{array}$ & $\begin{array}{l}\text { GR } \\
\left(\mathrm{kt} \mathrm{Cl}^{-} \text {year }^{-1}\right)\end{array}$ & $\begin{array}{l}\text { SG } \\
\left(\mathrm{kt} \mathrm{Cl}^{-} \text {year }^{-1}\right)\end{array}$ & $\begin{array}{l}\text { TG } \\
\left(\mathrm{kt} \mathrm{Cl}^{-} \text {year }^{-1}\right)\end{array}$ & $\begin{array}{l}\mathrm{FL} \\
\left(\mathrm{kt} \mathrm{Cl}^{-} \text {year }^{-1}\right)\end{array}$ \\
\hline 1997/1998 & 2.50 & 2.32 & & & & & \\
\hline 1998/1999 & 0.77 & 6.78 & & & & & \\
\hline $1999 / 2000$ & 1.20 & 4.67 & 2.58 & & & 3.04 & \\
\hline $2000 / 2001$ & 2.47 & 3.14 & 1.21 & & 0.51 & 0.79 & \\
\hline $2001 / 2002$ & 0.90 & 4.16 & 2.05 & & 5.70 & 1.58 & 0.17 \\
\hline $2002 / 2003$ & -0.60 & 3.85 & 2.62 & & 1.32 & 0.39 & 0.43 \\
\hline $2003 / 2004$ & 0.77 & 6.92 & 3.60 & & 7.28 & 2.10 & 0.50 \\
\hline $2004 / 2005$ & -1.03 & 6.73 & 5.53 & 6.57 & 7.26 & 2.35 & 0.47 \\
\hline $2005 / 2006$ & -2.17 & 7.35 & 5.40 & 7.96 & 10.9 & 3.90 & 0.46 \\
\hline $2006 / 2007$ & 3.43 & 2.13 & 1.18 & 3.05 & 5.69 & 2.01 & 0.28 \\
\hline $2007 / 2008$ & 1.93 & 3.54 & 1.18 & 4.90 & 3.90 & 1.46 & 0.42 \\
\hline $2008 / 2009$ & -1.10 & 7.44 & 3.67 & & & 2.04 & 0.57 \\
\hline $\begin{array}{l}\text { Correl. Coeff. } \\
\quad R\end{array}$ & & -0.81 & -0.88 & -0.99 & -0.52 & -0.39 & -0.57 \\
\hline $\begin{array}{l}\text { No. of } \\
\text { datasets }\end{array}$ & & 12 & 10 & 4 & 8 & 10 & 8 \\
\hline $\mathrm{kt} \mathrm{Cl}^{-} \mathrm{Deg}^{-1}$ & & -0.96 & -0.80 & -0.81 & -0.92 & -0.23 & -0.04 \\
\hline
\end{tabular}

Presented are all regions where we obtained data for several years

GR Graubünden, $S G$ St. Gallen, $T G$ Thurgau, $F L$ Principality of Liechtenstein

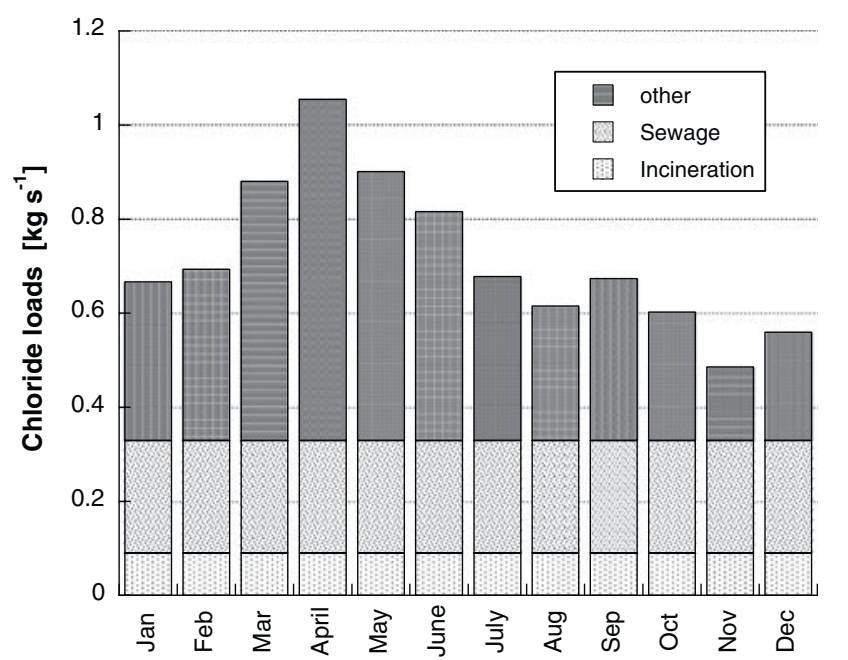

Fig. 6 Monthly averages of the chloride loads $\left(\mathrm{kg} \mathrm{s}^{-1}\right)$ in the Alpine Rhine calculated from NADUF monitoring data of the year 2006. Base loads are assumed from household sewage $\left(0.24 \mathrm{~kg} \mathrm{~s}^{-1}\right)$ and incineration plants $\left(0.09 \mathrm{~kg} \mathrm{~s}^{-1}\right)$

due to varying livestock composition and forage quality, minimum $\left(14 \mathrm{~kg} \mathrm{Cl}^{-}\right.$year $\left.^{-1}\right)$ and maximum values (67 $\mathrm{kg} \mathrm{Cl}^{-}$year $^{-1}$ ) deviate considerably from this estimated average. This large variability qualifies the reliability of the mentioned average based on only 16 analyses. However, considering the complete lacking of published information on this subject, we accept it as the best presently available estimate. In 2006, approximately 80,000 LU
Table 5 Content of $\mathrm{P}, \mathrm{N}$, and $\mathrm{Cl}^{-}$in different liquid manure samples

\begin{tabular}{llllrll}
\hline Sample no. & $\mathrm{TP}\left(\mathrm{g} \mathrm{L}^{-1}\right)$ & $\mathrm{TN}\left(\mathrm{g} \mathrm{L}^{-1}\right)$ & $\mathrm{Cl}\left(\mathrm{g} \mathrm{L}^{-1}\right)$ & $\mathrm{N}: \mathrm{P}$ & $\mathrm{Cl}: \mathrm{P}$ & $\mathrm{Cl}: \mathrm{N}$ \\
\hline 1 & 0.78 & 2.68 & 1.72 & 3.43 & 2.20 & 0.64 \\
2 & 0.08 & 1.93 & 0.65 & 24.83 & 8.33 & 0.34 \\
3 & 0.63 & 3.34 & 1.07 & 5.32 & 1.70 & 0.32 \\
4 & 0.04 & 0.28 & 0.06 & 7.57 & 1.70 & 0.22 \\
5 & 0.39 & 2.21 & 1.04 & 5.67 & 2.68 & 0.47 \\
6 & 0.62 & 2.42 & 1.23 & 3.93 & 1.99 & 0.51 \\
7 & 0.24 & 2.27 & 0.90 & 9.59 & 3.79 & 0.39 \\
8 & 0.24 & 1.53 & 0.22 & 6.40 & 0.94 & 0.15 \\
Average & 0.38 & 2.08 & 0.86 & 8.34 & 2.92 & 0.38 \\
\hline
\end{tabular}

lived in the catchment of the Alpine Rhine (Switzerland and Liechtenstein), 140,000 in the German, and 43,000 in the Austrian part of the catchment. Accordingly, farming loaded the cultivated land within these drainage basins with 3.4, 5.9, and $1.8 \mathrm{kt} \mathrm{Cl}^{-}$year ${ }^{-1}$. This estimate of chloride loading from livestock may double-count some chloride that enters the watershed through atmospheric deposition and is incorporated into forage. The error introduced by this approximation is expected to be small.

As Fig. 7 demonstrates, livestock decreased from 1980 to 2003 but was nearly constant since then. Its absolute numbers deviate from those mentioned above because the drainage basin of Lake Constance is only a fraction of the region on which Fig. 7 is based on. However, as we assume 


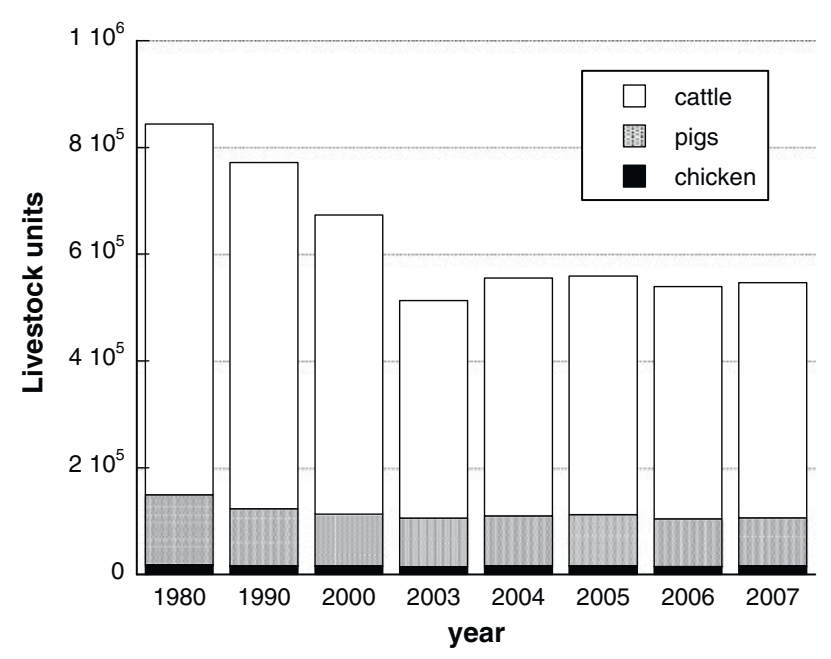

Fig. 7 Total livestock summarized from Switzerland, Germany, Austria and Liechtenstein in the 'Lake Constance Region' (which, in the case of Germany, corresponds only to about $50 \%$ to the hydrological catchment) for the years 1980-2007 expressed in livestock units (corresponding to $15 \mathrm{~kg} \mathrm{P}$ and $105 \mathrm{~kg} \mathrm{~N}$ ). One cattle, pig or chicken corresponds to $0.638,0.131$, or 0.007 livestock units, respectively. (Numbers from Germany were missing in 2006 and were interpolated between 2005 and 2007.)

that this trend also applies to the catchment of Lake Constance, the presented results suggest that livestock husbandry cannot explain the most recent increase in the lake's chloride concentration.

\section{Overall budget}

For 2006, we itemized the various chloride imports to the total catchment of Upper Lake Constance in Table 2. Deicing salt, wastewater, manure, soil weathering, precipitation, and solid waste incineration contributed 52, 23, 11, 9, 3 and $3 \%$ to the total load of $101 \mathrm{kt} \mathrm{Cl}^{-}$year ${ }^{-1}$ within the catchment. In 2006, the total chloride import to the catchment exceeded its loss via tributaries and direct input to Lake Constance (69.7 kt year ${ }^{-1}$ ) by $45 \%$ (31.6 kt year $\left.{ }^{-1}\right)$, suggesting that this fraction was transiently stored in the soil or groundwater. Recent investigations by Rhodes et al. (2001) and Bastviken et al. (2006, 2007) confirm that chloride originating from deicing salts is not readily washed out during the following spring but may be retained in the soil and eluted over many years. This is supported by a study of environmental consequences of road salt application in Austria by Wresowar and Sieghardt (2000), and more recently by Lundmark and Olofsson (2007), who estimated that about 40 and $45 \%$ respectively, of the street salt was dispersed to the roadside and adjacent land by tires and wind, explaining why the runoff of deicing salts may be strongly retarded.

If we subtract the amount of deicing salt $\left(52.2 \mathrm{kt} \mathrm{year}^{-1}\right)$ from the total chloride imports to the catchment (101 kt year ${ }^{-1}$ ) and divide this difference (48.8 $\mathrm{kt} \mathrm{year}^{-1}$ ) by the average annual water discharge $\left(1.16 \times 10^{10} \mathrm{~m}^{3}\right.$ year $\left.{ }^{-1}\right)$, we obtain the expected average chloride concentration of the water reaching Lake Constance if no deicing salts were applied in its drainage basin $\left(4.2 \mathrm{~g} \mathrm{~m}^{-3}\right)$. Here, we implicitly assume that the use of deicing salt was negligible before the early 60s. As chlorides are known to behave conservatively in lakes, this value represents the expected lake concentration. Hence, the chloride concentration in the lake could have risen from $2.5 \mathrm{~g} \mathrm{~m}^{-3}$ in 1961 to $4.2 \mathrm{~g} \mathrm{~m}^{-3}$ but not to the present $6.1 \mathrm{~g} \mathrm{~m}^{-3}$ if no deicing salts were applied. Road salt application is, therefore, responsible for an increase of $6.1-4.2=1.9 \mathrm{~g} \mathrm{~m}^{-3}$, or $45 \%$, of the observed increase since 1961 . The remaining 55\% must be attributed mainly to household wastewater and changing farming practices. If all chloride that is emitted in the catchment annually (101 kt) would reach the lake without delay, the expected concentration of chloride in Lake Constance would rise to $8.8 \mathrm{~g} \mathrm{~m}^{-3}$.

\section{Summary and conclusions}

The good agreement between monitored chloride input by tributaries, the chloride export from the lake (Table 3) and the increase in the lake's concentration (Fig. 5) indicates that this study has captured all relevant sources of chloride to the lake. Averaged over the last 13 years, the lake received a total of $60 \mathrm{kt}$ of chloride per year. The River Rhine contributed about one-third, and two-thirds originated from the remaining catchment drained by various small rivers, as well as via direct wastewater discharge into the lake. In other words, the largest tributary, the River Rhine, can neither explain the evolution nor the present chloride concentration of Lake Constance.

The collected data indicate that in moderate to densely populated catchments characterized by cold and wet winters, anthropogenic activities, e.g., deicing, wastewater production and farming, might increase the natural chloride transport to the lake almost ninefold (Table 2).

Although chloride behaves conservatively, applied as deicing salt to streets or with liquid manure to cultivated land, it can be transiently stored in the soil, retarding its transport to surface waters.

Finally, we conclude that the observed increase in the chloride concentration in Lake Constance is due to about $45 \%$ by road deicing salts, whereas wastewater, farming, and incineration of solid wastes are responsible for the remaining $55 \%$.

The present chloride concentration in Lake Constance is clearly below levels where adverse biological effects could be traced. However, this work documents that 
anthropogenic activities can increase the fluxes of elements and accelerate natural element cycling significantly, in the case of chloride in the Lake Constance catchment, by a factor of almost nine.

To our knowledge this is the first study dealing with the chloride budget of a lake with a surface area as large as $470 \mathrm{~km}^{2}$ and a drainage basin extending over $11,000 \mathrm{~km}^{2}$. Obviously, combining gathered puzzle pieces of information and interpolating missing links can result at best in an approximation rather than in a pin-sharp precise picture of reality. However, if this paper succeeds in stimulating discussion and provokes additional, possibly controversial studies, it fully attained its goal.

Acknowledgments The contributions of a large number of people are gratefully acknowledged. Data provided: Lucia Walser, Institut für Umwelt und Lebensmittel, Ralf Grabher, Amt für Wasserwirtschaft, and Walter Heine, Abteilung Landwirtschaft, Bregenz, Land Vorarlberg, Austria-Harald Hetzenauer, LUBW, Landesanstalt für Umwelt, Messungen und Naturschutz Baden-Württemberg, Germany-Hans Mehlhorn, Zweckverband Bodensee-Wasserversorgung, Stuttgart-Hendrik Roggendorf, Amt für Baurecht und Umwelt, Konstanz-Klaus Ruff, Landratsamt Ravensburg-Rony Bargetze, Tiefbauamt Fürstentum Liechtenstein-Beat Calonder and Michael Holzer, Amt für Natur und Umwelt, Graubünden, Chur-Oliver Radecke, Tiefbauamt Graubünden, Chur-Valentin Luzi, Amt für Landwirtschaft und Geoinformation, Chur-Michael Eugster, Amt für Umwelt und Energie, St. Gallen-H.J. Zwingli, Landwirtschaftsamt des Kt. St. Gallen-Beat Baumgartner and Heinz Ehmann, Amt für Umwelt Kanton Thurgau, Frauenfeld-Aurel Weisswange, Bundesamt für Umwelt, Bern-Fritz Birrer, Amt für Landwirtschaft und Wald (lawa) des Kt. Luzern-Robert Lovas and Ernst Butscher, Umwelt und Energie (uwe) des Kt. Luzern-Christian Rixen, WSL, Institute for Snow and Avalanche Research, Davos-Ursi Schönenberger, Rosi Siber and Renata Hari, Eawag. Air temperature and precipitation data were kindly provided by the Swiss Meteorological Institute (MeteoSchweiz). Martin Schmid helped with the Kendalltests. Jürg Zobrist and Johny Wüest are acknowledged for discussions and comments on the manuscript, Patricia Achleitner for the graphics, and Ruth Stierli for her careful work in the laboratory. We also thank two anonymous reviewers for their thorough and helpful suggestions.

\section{References}

Bastviken D, Sandén P, Svensson T, Stahlberg C, Magounakis M, Öberg G (2006) Chloride retention and release in a boreal forest soil: effects of soil water residence time and nitrogen and chloride loads. Environ Sci Technol 40:2977-2982

Bastviken D, Thomsen F, Svensson T, Karlsson S, Sandén P, Shaw G, Matucha M, Öberg G (2007) Chloride retention in forest soil by microbial uptake and by natural chlorination of organic matter. Geochim Cosmochim Acta 71(13):3182-3192

Bodensee Wasserversorgung, Zweckverband. http://www.zvbwv.de

CRU 1961-1990. Climatic Research Unit, Global climate dataset 30 year-mean from 1961-1990. http://www.ipcc-data.org/

DEW (2002) German standard methods for the examination of water wastewater, and sludge (in German). Wiley, Weinheim

EPA (2001) Parameters of water quality. Interpretation of standards. Environmental protection agency, Ireland. http://www.epa.ie/ rivermap/docs/Parameters.pdf
Eyles N, Meriano M (2010) Road-impacted sediment and water in a Lake Ontario watershed and lagoon, City of Pickering, Ontario, Canada: an example of urban basin analysis. Sediment Geol 224: $15-28$

Federal Office for the Environment (FOEN) (1963), Hydrological data of the River Rhine at Neuhausen. http://www.hydrodaten. admin.ch/e/2288.htm

Federal Office for the Environment (FOEN) (2007), Hydrological data of the River Rhine at Diepoldsau. http://www.hydrodaten. admin.ch/e/2473.htm

FOEFL (1994) Guidelines for water protection in agriculture-subject: farm manure. Federal Office for Agriculture (FOA), Federal Office of Environment, Forests and Landscape (FOEFL), Switzerland

Gurtz J, Lang H, Luft G, Strobel F, Wagner G (1997) Untersuchung der Wasserbilanz des Bodensees. Geographical Institute of ETH Zurich, Reports and scripts 61 (in German)

Hart BT, Bailey P, Edwards R, Hortle K, James K, McMahon A, Meredith C, Swadling K (1991) A review of the salt sensitivity of the Australian freshwater biota. Hydrobiologia 210:105-144

Howard KWF, Maier H (2007) Road de-icing salt as a potential constraint on urban growth in the Greater Toronto Area, Canada. J Contam Hydrol 91:146-170

IGKB, Green report no. 35 (2007): Limnologischer Zustand des Bodensees. http://www.igkb.com/pdf/gb/gb35_gesamtbericht.pdf

Kaushal SS, Groffman PM, Likens GE, Belt KT, Stack WP, Kelly VR, Band LE, Fisher GT (2005) Increased salinization of fresh water in the northeastern United States. PNAS 102/38:1351713520. doi:10.1073pnas.0506414102

Kelly WR (2008) Long-term trends in chloride concentrations in shallow aquifers near Chicago. Ground Water 46(5):772-781

Kelly VR, Lovett GM, Weathers KC, Findlay SEG, Strayer DL, Burns DJ, Likens GE (2008) Long-term sodium chloride retention in a rural watershed: legacy effects of road salt on streamwater concentration. Environ Sci Technol 42:410-415

Klee RJ, Graedel TE (2004) Elemental cycles: a status report on human or natural dominance. Annu Rev Environ Resour 29:69-107

Lundmark A, Olofsson B (2007) Chloride deposition and distribution in soils along a deiced highway-assessment using different methods of measurement. Water Air Soil Pollut 182:173-185

Meriano M, Eyles N, Howard KWF (2009) Hydrogeological impacts of road salt from Canada's busiest highway on a Lake Ontario watershed (Frenchman's Bay) and lagoon, City of Pickering. J Contam Hydrol 107:66-81

Moosmann L, Müller B, Gächter R, Wüest A, Butscher E, Herzog P (2005) Trend-oriented sampling strategy and estimation of soluble reactive phosphorus in streams. Water Resour Res 41:W01020. doi:10.1029/2004WR003539

NABEL (2007): Swiss National Air Pollution Monitoring Network Luftbelastung 2007, (Table 24). Federal Office for the Environment (FOEN) and Swiss Institute for Material Science and Technology (EMPA). Berne. http://www.bafu.admin.ch/ publikationen/publikation/00099/index.html?lang=de

NADUF databank at Eawag (2009). http://www.eawag.ch/organisation/ abteilungen/wut/schwerpunkte/chemievonwasserresourcen/naduf/ Rhein-Diepoldsau.19.xls

Novotny EV, Murphy D, Stefan HG (2008a) Increase of urban lake salinity by road deicing salt. Sci Total Environ 406:131-144

Novotny EV, Sander A, Mohseni O, Stefan H (2008b) A salt (chloride) balance for the Minneapolis/St. Paul metropolitan area environment. Project Report no. 513, University of Minnesota, St. Anthony Falls Laboratory, Minneapolis

Petranka JW, Doyle EJ (2010) Effects of toad salts on the composition of seasonal pond communities: can the use of road salts enhance mosquito recruitment? Aquat Ecol 44:155-166 
Petri M (2006) Water quality of Lake Constance. Hdb Environ Chem 5 (part L). Springer, Heidelberg, pp 127-138. doi:10.1007/698 5_018. http://www.springerlink.com/index/y64254g0rn7kp151.pdf

Rhodes AL, Newton RM, Pufall A (2001) Influences of land use on water quality of a diverse New England watershed. Environ Sci Technol 35:3640-3645

Rossknecht H (1998) Langjährige Entwicklung chemischer Parameter im Bodensee. IGKB report no. 48. http://www.igkb.de/html/bb/ content_48.html

Thunqvist E-L (2004) Regional increase of mean chloride concentration in water due to the application of deicing salt. Sci Total Enviriron 325:29-37

Trowbridge PR, Kahl JS, Sassan DA, Heath DL, Walsh EM (2010) Relating road salt to chloride water quality violations in New
Hampshire streams: a simple method for TMDL studies. Environ Sci Technol 44:4903-4909. doi:10.1021/es100325j

Vorarlberg ORF 2009. http://oesterreich.orf.at/vorarlberg/stories/ 408162

Williams DD, Williams NE, Cao Y (1999) Road salt contamination of groundwater in a major metropolitan area and development of a biological index to monitor its impact. Water Res 34(1):127-138

Wresowar M, Sieghardt M (2000) Studie über die Auswirkung stickstoffhaltiger Auftaumittel. Expert report. Institute for forest ecology, University for soil culture, Vienna

Zobrist J, Reichert P (2006) Bayesian estimation of export coefficients from diffuse and point sources in Swiss watersheds. J Hydrobiol 329:207-223 